\title{
Costly External Finance and Investment Efficiency in a Market
}

\section{Equilibrium Model}

\author{
Ján Zábojník*
}

March 24, 2008

\begin{abstract}
The corporate finance literature suggests that a financially constrained firm invests less than an identical unconstrained firm. This does not imply that financial frictions cause firms to invest less than in a frictionless economy. When firms compete for investment funds, an increase in financial frictions can lead individual firms to increase their investment levels. A greater than the frictionless level of investment is likely in low productivity firms, in cash-rich firms, and in firms with cheap external capital. Government programs that make capital cheaper for small firms may lead to lower levels of investment for all firms and decrease efficiency.
\end{abstract}

Journal of Economic Literature Classification numbers: O16, E22, E44, G20

\footnotetext{
${ }^{*}$ Department of Economics, Queen's University, Kingston, Canada. Fax: (613) 533-6668. E-mail: zabojnik@econ.queensu.ca. I would like to thank John Matsusaka, Oguzan Ozbas, and two referees for helpful comments and suggestions. I have also benefited from discussions with Huw Lloyd-Ellis, Fulvio Ortu, and David Scharfstein.
} 


\section{Introduction}

A large body of research has stressed the quality of a country's financial markets as an important determinant of the firms' real investments and of economic development and growth. ${ }^{1}$ But how exactly is investment affected by financial market imperfections? A key result in the corporate finance literature says that a financially constrained firm invests less than an identical unconstrained firm and that the more financially constrained the firm is the less it invests; see e.g. Rajan and Zingales (1997), Hubbard (1998), and Stein (2003). It seems natural to conclude from this that when external finance is associated with a deadweight cost, firms invest less than when markets are frictionless. $^{2}$

This paper shows that in assessing how financing frictions distort investment, one needs to distinguish whether the external cost is idiosyncratic to a given firm or whether it affects the whole economy. In particular, the frequently used case of an otherwise identical unconstrained firm is not the appropriate first-best benchmark when the external cost affects all firms in the economy, as for example when it reflects the country's legal and financial institutions, its bankruptcy procedures, protection of minority shareholders, stock market regulations regarding the disclosure of information, and so on. Such common factors have market-wide effects, so the appropriate first-best benchmark is the investment level that would be chosen by the firm in an economy with perfect capital markets. It is shown here that economy-wide financial frictions can easily lead firms to invest more than under frictionless markets. Similarly, unlike in the case of idiosyncratic external costs, a higher common external cost can lead to greater levels of investment by individual firms.

The argument is as follows. Suppose that new firms can be established as long as they can find

\footnotetext{
${ }^{1}$ Boyd and Smith (1992), Bencivenga et al (1995), Aghion and Bolton (1997), Bernhardt and Lloyd-Ellis (2000), and Shleifer and Wolfenzon (2002) represent a small sample of this diverse literature. Banerjee and Duflo (2005) and Levine (2005) provide surveys.

${ }^{2}$ For example, Stein (2003, p. 114) argues that the models of costly external finance "unambiguously predict underinvestment relative to a first-best benchmark." Similarly, Hubbard (1998, p. 197) concludes that in the presence of external costs, the equilibrium capital stock "is less than the first-best desired capital stock in a frictionless setting."
} 
enough internal or external funds to finance their operations. To make things simple, assume also that all firms in the economy are identical, so that in equilibrium each firm earns zero expected profit. Then if a deadweight cost is introduced into external finance, the equilibrium interest rates must fall in order to allow the firms to break even - otherwise, no firm would be willing to raise external finance. The decrease in the equilibrium rate of return tends to decrease the firms' marginal costs of investment, which works against the direct effect of the higher external cost. I provide simple necessary and sufficient conditions under which this indirect, market equilibrium effect prevails, so that costly external finance leads each firm to overinvest, i.e. to invest more than it would in a frictionless economy. More specifically, I show the following:

- When all firms are identical, then each firm overinvests if at the first best level of investment the marginal external cost is smaller than the average external cost. Each firm underinvests if the reverse is true.

- Less productive firms are more likely to overinvest than more productive firms. By the same token, more productive firms are more likely to underinvest.

- Cash rich firms and firms with relatively cheap external capital have a greater tendency to overinvest, while cash poor firms and firms with relatively costly external capital have a greater tendency to underinvest.

- Firms with free cash always overinvest compared to the first best level. Thus, free cash causes overinvestment in the present model as in Jensen (1986), although for a different reason.

- An increase in the cost of external finance can make some firms better off and also improve efficiency.

All of the above results hold whether the economy is closed or open to capital flows. These results suggest that while the level of capital market frictions is an important determinant of the 
firms' investments, so is the composition of the costs associated with these frictions. Moreover, the results highlight the fact that the aggregate level of investment is not a sufficient measure of investment inefficiencies brought about by financing imperfections. In particular, the results show that capital market frictions cause misallocation of resources across firms - some firms invest too much and some invest too little compared to the optimal frictionless level. As shown by Restuccia and Rogerson (2007), misallocation of resources across firms can have significant effects on a country's aggregate output and total factor productivity. In the context of policy distortions that create heterogeneity in the prices faced by individual producers, their calibrations show that idiosyncratic investment distortions can lead up to a 50 percent decrease in output and TFP.

In the finance literature, Shleifer and Wolfenzon (2002) build a framework similar to the one employed in this paper and use it to provide an explanation for several cross-country empirical regularities that tie the effectiveness of a country's judicial system to corporate finance. ${ }^{3}$ While the main focus of the present paper is on clarifying the theoretical relationship between the costs of external finance and the efficiency of capital allocation rather than on explaining empirical regularities, the model also offers some empirical and policy implications that are complementary to those obtained by Shleifer and Wolfenzon:

- The government programs observed in many countries that make it easier for small firms to obtain investment funds may actually lead to lower equilibrium levels of investment for all firms and decrease efficiency.

- The most productive and cash rich firms may benefit from the presence of a cost associated with external finance. Such firms might therefore have an incentive to oppose reforms aimed at improving the financial system, consistent with the observation of La Porta et al (2000)

\footnotetext{
${ }^{3}$ Another recent market equilibrium model that studies the efficiency of capital allocation when financial markets are imperfect is Almeida and Wolfenzon (2005), whose focus is on the reallocation of capital to and from existing projects and on the effects of conglomeration.
} 
and other authors.

- The possibility of equilibrium overinvestment due to financial markets frictions suggests caution when interpreting empirical studies that link investment levels and the average firm size in a country to the quality of the country's financial and legal systems. For example, if a study finds that the countries with better legal protection of investors have larger firms ${ }^{4}$, this does not necessarily mean that those countries also have more efficient firms.

The rest of the paper proceeds as follows. Section 2 introduces the basic model with identical firms competing for costly external funds. Section 3 derives the paper's main results. It shows that a cost associated with external finance can lead to overinvestment relative to the frictionless level and provides a necessary and sufficient condition for this outcome. It also contains an analysis of the model when firms differ in the quality of their projects, in available cash, and in their costs of external capital. Finally, the section investigates the robustness of the results to the case where the economy is open to capital flows from a foreign country. Section 4 discusses some empirical evidence and policy implications and demonstrates that big firms can benefit from a deadweight cost in external finance. Section 5 concludes.

\section{The Model}

Consider a closed economy with free entry of identical non-atomic firms. As will be shown later, the main qualitative results continue to hold when the firms are heterogeneous and the economy is open to capital flows from another country.

A representative firm in this economy has access to a single, one-period investment project. If this firm invests an amount $I$ at the beginning of the period, its expected revenue at the end of the

\footnotetext{
${ }^{4}$ See, e.g., Kumar, Rajan, and Zingales (2002).
} 
period is $f(I)$. The investment function $f():. \mathbb{R}^{+} \rightarrow \mathbb{R}^{+}$is given by

$$
\begin{array}{ll}
f(I)=0 & \text { for } I \leq F, \text { and } \\
f(I)=V(I) & \text { for } I \geq F,
\end{array}
$$

where $F>0$ is a fixed cost associated with the firm's entry into the market and $V(I)$ is an increasing, concave and differentiable function, with $V(F)=0$ and $\lim _{I \rightarrow \infty} V^{\prime}(I)=0$.

Each firm has an initial cash reserve $w \geq 0$. For the main part of the analysis it will be assumed that $w \leq F$, so that no firm can invest profitably without raising external resources. I will relax this assumption in Subsection 3.4 and show that the qualitative results continue to hold even if only some firms need outside capital.

A firm can do two things with its funds. First, it can supply investment funds to other firms, either directly or through financial intermediaries (not modelled here). This yields the rate of return $r$, which is endogenous and will be determined as part of the equilibrium. Alternatively, the firm can invest in its own project. If a firm decides to invest an amount $I>w$ in its own project, it has to seek external financing for the difference $e=I-w$.

External resources are costly. The literature has identified several sources of friction that put a wedge between the cost of a firm's external and internal investment funds. External funds can be costly due to asymmetric information and adverse selection, as in Myers and Majluf (1984) and Greenwald, Stiglitz and Weiss (1984), debt overhang, as in Myers (1977), or incomplete contracting and costly state verification, as in Townsend (1979) and Gale and Hellwig (1985). ${ }^{5}$ In modeling this cost, I will follow Froot, Scharfstein and Stein (1993), Kaplan and Zingales (1997), Matsusaka and Nanda (2002), and others, and assume that if a firm invests $I>w$, then in addition to foregoing the

\footnotetext{
${ }^{5}$ For surveys of this literature see, e.g., Harris and Raviv (1991) and Stein (2003).
} 
market rate of return $r$ on the whole amount $I$, it has to bear a deadweight $\operatorname{cost} c(\theta, e)$ associated with raising the amount $e$. The parameter $\theta$ is a measure of frictions in the external capital markets - the higher is $\theta$, the higher is the deadweight cost of raising a given amount $e .{ }^{6}$

The cost function $c(\theta, e)$ is differentiable in both arguments; its derivative with respect to $x \in\{\theta, e\}$ will be denoted as $c_{x}(\theta, e)$. In addition to $c_{\theta}(\theta, e)>0$ assumed above, $c(\theta, e)$ is nondecreasing and convex in $e: c_{e}(\theta, e) \geq 0$ and $c_{e e}(\theta, e) \geq 0$.

At the beginning of the period, all firms simultaneously approach outside investors with their investment proposals, in an attempt to raise external funds, $e$. The total amount of investment funds available in this economy (including the firms' cash reserves, $w$ ) is given by the supply function $S(r)$, which is weakly increasing in the interest rate, $r$. In this setting, the equilibrium interest rate is determined by supply of and demand for investment funds. In particular, each investor offers financing to those firms that promise the highest rate of return. At the same time, the projects that firms propose to undertake must be credible, that is, if a firm proposes to invest an amount $I$, it cannot promise to repay more than $f(I)$ at the end of the period. Finally, due to the free entry of firms, the equilibrium interest rate must be such that each firm earns zero economic profit.

\section{The Analysis}

\subsection{The equilibrium level of investment}

Each firm chooses its investment level $I$ and the amount of external financing $e$, so as to maximize its profit $\pi(I, e, \theta, w)=f(I) /(1+r)-I-c(\theta, e)$, subject to the financing constraint $I \leq w+e$. Because external capital is costly, no firm will raise more than the minimum amount needed to finance the chosen level of investment, so that $e=I-w$. Moreover, if a firm invests a positive

\footnotetext{
${ }^{6}$ As pointed out by Stein (2003), this reduced-form specification of capital market frictions is more general than it may seem. Stein (1998) shows that it corresponds to a version of the Myers and Majluf's (1984) adverse-selection model and Froot, Scharfstein and Stein (1993) map it into a variant of the costly-state-verification models of Townsend (1979) and Gale and Hellwig (1985).
} 
amount, then it must be that $I>F$, so that $f(I)=V(I)$; otherwise the profit would be negative. Substituting to the objective function, the representative firm's maximization problem becomes

$$
\max _{e} V(w+e) /(1+r)-w-e-c(\theta, e)
$$

The associated first order condition then says that if the firm invests, it chooses the $e^{*}(w, \theta)$ given by

$$
\frac{V^{\prime}\left(w+e^{*}(w, \theta)\right)}{1+c_{e}\left(\theta, e^{*}(w, \theta)\right)}=1+r
$$

It will be assumed from now on that $\pi\left(e^{*}(w, \theta), \theta, w\right)>0$, so that the firms operate at a positive scale. $^{7}$ Then $e^{*}(w, \theta)$ is the equilibrium level of external financing, which uniquely defines the equilibrium level of investment: $I^{*}(w, \theta)=w+e^{*}(w, \theta)$.

Free entry of firms drives their expected profits to zero. This implies that the equilibrium rate of return, $r^{*}(w, \theta)$, must be such that $V\left(w+e^{*}(w, \theta)\right) /\left(1+r^{*}(w, \theta)\right)-I^{*}(w, \theta)-c\left(\theta, e^{*}(w, \theta)\right)=0$, that is,

$$
\frac{V\left(w+e^{*}(w, \theta)\right)}{w+e^{*}(w, \theta)+c\left(\theta, e^{*}(w, \theta)\right)}=1+r^{*}(w, \theta) .
$$

Combining the first order condition (1) with the zero profit constraint (2) yields the following condition, which defines the equilibrium level of investment:

$$
V^{\prime}\left(I^{*}(w, \theta)\right) I^{*}(w, \theta)-V\left(I^{*}(w, \theta)\right)=V\left(I^{*}(w, \theta)\right) c_{e}\left(\theta, e^{*}(w, \theta)\right)-V^{\prime}\left(I^{*}(w, \theta)\right) c\left(\theta, e^{*}(w, \theta)\right) .
$$

It will be shown in the proof of Proposition 1 that a solution to (3) exists. Moreover, because the left hand side of $(3)$ decreases and the right hand side increases in $e^{*}(w, \theta)$ and $I^{*}(w, \theta)$, the

\footnotetext{
${ }^{7}$ Note that due to the presence of fixed costs and of deadweight costs of external finance, the usual condition $V^{\prime}(F)=\infty$ is not sufficient to guarantee that $\pi\left(e^{*}(w, \theta), \theta, w\right)>0$. Instead, $V($.$) needs to be "sufficiently large" and$ $F$ and $c$ need to be "sufficiently small."
} 
solution is unique. Note also that the equilibrium investment level for each individual firm, $I^{*}(w, \theta)$, is independent of the overall supply of investment funds in the economy, $S(r)$.

In a frictionless world, the optimal level of investment, $I^{f}$, would be given by

$$
V^{\prime}\left(I^{f}\right) I^{f}-V\left(I^{f}\right)=0 .
$$

I will refer to the benchmark investment level $I^{f}$ as the first best level. As can be seen by comparing conditions (3) and (4), costly external finance in general causes firms to distort their investment levels away from the first best level. I will say that a firm "overinvests" when $I^{*}(w, \theta)>I^{f}$ and "underinvests" when $I^{*}(w, \theta)<I^{f}$.

\subsection{Investment distortion}

Focusing on an individual firm in isolation, the previous work has established that if the firm's external capital is costly, the firm will underinvest, that is, $I^{*}<I^{f}$ (from now on, the notation will suppress the dependence of $I^{*}, e^{*}$, and $r^{*}$ on $w$ and $\left.\theta\right)$. Moreover, when the external cost rises, the firm decreases its investment level, that is, $\partial I^{*} / \partial \theta \leq 0$; see e.g. Kaplan and Zingales (1997) and Stein (2003).

These conclusions extend to the present framework if the variable of concern is the aggregate level of investment, i.e. the sum of the investments undertaken by all firms in the economy: ${ }^{8}$

Proposition 1. Let $I_{A}^{*}$ denote the equilibrium aggregate level of investment in the economy, i.e. $I_{A}^{*}=n^{*} I^{*}$, where $n^{*}$ is the equilibrium number of firms, and let $I_{A}^{f}$ be the first-best aggregate level of investment. Then

(i) $I_{A}^{*}<I_{A}^{f}$ and $\frac{\partial I_{A}^{*}}{\partial \theta}<0$ if $S(r)$ is strictly increasing; and

\footnotetext{
${ }^{8}$ All proofs are in the Appendix.
} 
(ii) $I_{A}^{*}=I_{A}^{f}$ and $\frac{\partial I_{A}^{*}}{\partial \theta}=0$ if $S(r)$ is perfectly inelastic.

Thus, if outside capital is costly, the aggregate level of investment is (weakly) smaller than would be efficient. However, the corporate finance literature has typically focused on the relationship between external costs and the investment levels of individual firms. For individual investment levels, the standard partial equilibrium conclusions do not extrapolate into a market equilibrium setting. Looking first at the underinvestment result, this is demonstrated in the following proposition.

Proposition 2. If external capital is costly, then each firm overinvests compared to the first best level $\left(I^{*}>I^{f}\right)$ if

$$
c_{e}\left(\theta, e^{f}\right)<\frac{c\left(\theta, e^{f}\right)}{I^{f}}
$$

and underinvests $\left(I^{*}<I^{f}\right)$ if the reverse is true.

Thus, costly external finance can result in overinvestment relative to the frictionless level. As shown by Corollary 1 below, one can easily find examples of cost functions such that condition (5) is satisfied.

Corollary 1. Suppose firms have no internal funds $(w=0)$ and the deadweight cost of external capital is given by $c\left(\theta, e^{f}\right)=\alpha(\theta)+\beta(\theta)$ e, where $\alpha(\theta)>0$ and $\beta(\theta) \geq 0$ are increasing functions of $\theta$. Then external cost of finance always causes overinvestment: $I^{*}>I^{f}$.

The logic behind the above two propositions and the corollary is as follows. First, financial frictions in the present framework lead to a decrease in the equilibrium interest rate, because the introduction of the deadweight $\operatorname{cost} c(\theta, e)$ would cause the firms to lose money if the interest rate remained at the frictionless level $r^{f}$. Therefore, the interest rate must fall to induce the firms to seek external financing. This is counter to the intuition one might have based on the models of financial contracting in which asymmetric information and agency problems lead investors to increase the 
price of the investment funds, thus in effect passing on to the firm the expected cost that arises due to the contracting imperfections. Note, however, that because they also bear the external cost $c$, the "effective" interest rate faced by the firms may or may not be lower than the frictionless rate. Second, the fall in interest rates causes the aggregate amount of supplied funds to decrease if $S(r)$ is upward sloping, which in equilibrium translates into a decrease in the aggregate level of investment. Finally, to see why the firms' individual investments can increase, note that if the fixed deadweight cost of external financing is relatively large compared to the marginal deadweight cost, as in the example of Corollary 1, then the resulting break-even interest rate $r^{*}$ is very low. But this means that the marginal cost of investment is also low (lower than in a frictionless world), which induces each firm to overinvest..$^{9,10}$

Perhaps it is worth reiterating that under- and over-investment are measured compared to the first best level, which is the level of investment that the firms would choose if capital markets were perfect. However, holding the rate of return fixed, if there were two groups of firms in this economy, one with a higher marginal cost of external capital than the other, then the group with the higher cost would invest less ("underinvest") compared to the group with the lower cost. This is the standard partial equilibrium result, which has been the focus of the previous literature. The importance of Proposition 2 is in demonstrating that this partial equilibrium observation cannot be invoked to conclude that when capital markets are imperfect, individual firms underinvest relative to the frictionless level.

The second insight from Propositions 1 and 2 is that the aggregate distortions due to costly

\footnotetext{
${ }^{9}$ More precisely, the firms that in equilibrium choose positive levels of investment overinvest. This can hold together with aggregate underinvestment only if some firms completely shut down their operations, which in a sense means that they underinvest.

${ }^{10}$ In addition to the effects described in the text, there could be secondary effects on investment through the (unmodelled) factor markets. For example, suppose that production requires labor. By decreasing the equilibrium aggregate level of investment, $I_{A}^{*}$, an external cost of financing should also cause a fall in the aggregate demand for labor and depress real wages. This in turn should further boost each individual firm's investment level, magnifying the effects analyzed in this paper.
} 
external finance differ in their nature from the distortions at individual firms. For example, it is possible that each individual firm deviates from the first-best level of investment, but the aggregate investment remains at the first-best, frictionless level. The reverse situation is also possible. Thus, to get a complete picture of how capital market imperfections affect the allocation of investment funds in the economy, one has to consider both the aggregate and the individual level distortions. This conclusion is in line with the point made by Restuccia and Rogerson (2007), who also stress the importance of distortions at the level of individual producers. Restuccia and Rogerson's calibrations indicate that policies that lead firms to idiosyncratic investment distortions can cause up to a 50 percent decrease in output and TFP.

\subsection{The effects of an increase in the cost of external finance}

Treating the rate of return as exogenous, Kaplan and Zingales (1997) show that a firm's investment level always weakly decreases in the cost of external finance. In the present model, an increase in the deadweight cost of external finance can lead to an increase in the equilibrium level of investment for each firm. This is illustrated in Proposition 3 below for a class of linear cost functions.

Proposition 3. Let $c(\theta, e)=\theta(A+e)$, where $A \geq 0$ is a constant. Then $\frac{\partial I^{*}(\theta)}{\partial \theta}>0$ if $A>w$, $\frac{\partial I^{*}(\theta)}{\partial \theta}<0$ if $A<w$, and $\frac{\partial I^{*}(\theta)}{\partial \theta}=0$ if $A=w$.

Thus, when the deadweight cost of external funds is linear with a relatively large fixed cost, each firm's equilibrium level of investment increases in the degree of financing friction. For example, if firms have no internal resources $(w=0)$, then the equilibrium level of investment increases in the cost of external capital whenever external capital is associated with some positive fixed cost. On the other hand, when $w=0$ and external funding entails no fixed cost $(A=0)$, then the individual investments are always at the first best level, $I^{*}=I^{f}$, no matter how costly are the external funds. In this case the deadweight cost of external finance is completely offset by a decrease in the 
equilibrium rate of return. The cost of external finance is then reflected solely in the equilibrium number of firms and in the equilibrium aggregate level of investment.

The literature on financial frictions and development has for the most part focused on how the allocation of resources and a country's economic development depend on the degree of financial market imperfections. Propositions 2 and 3 suggest that it is equally important to consider the composition of the deadweight costs. The larger is the fixed cost of external finance, and the smaller is the marginal cost, the larger should be the average size of the firms operating in the given economy. ${ }^{11}$ The fixed costs associated with external financing can include, for example, a part of the decline in the stock price upon the announcement of a stock issue, government taxes and fees, fixed fees paid to the underwriter, and so on. These factors direct the flow of resources towards a relatively small number of large firms. The marginal costs include any cost that depends upon the amount of the capital raised in the external markets. For example, agency costs should be higher the higher is the percentage of a firm's stock held by outside investors, underwriters' marketing costs may be increasing in the size of the equity issue, expected bankruptcy costs increase with the amount of debt, and so on. In the present model, these factors tend to direct resources towards a relatively large number of smaller firms.

\subsection{The efficiency of investment when firms are heterogenous}

This subsection extends the above analysis to a setting with heterogenous firms; it also allows for the possibility that some firms are able to finance all their investments internally. In particular, assume that the economy has a measure 1 of potential firms parameterized by $t$, which is distributed on $[0,1]$ according to a cumulative distribution function $G(t)$. The parameter $t$ will be given three

\footnotetext{
${ }^{11}$ Obviously, the model ignores dynamic considerations, which could play an important role. For example, if firms could time their investments, large fixed costs of external finance could lead them to invest larger amounts, but less frequently.
} 
alternative interpretations. Accordingly, let $t \in\{\theta, \phi, \eta\}$. When $t=\theta$, the firms differ in the costs they face when raising external funds, where, in contrast to the previous analysis, each firm can have a different $\theta$. As before, $c_{\theta}(\theta, e)>0$; in addition, $c_{e \theta}(\theta, e)>0$. When $t=\phi$, the firms differ in projects they have access to: $f(I)=V(I, \phi)$ for $I \geq F$, where $V_{\phi}(I, \phi)>0$ and $V_{I \phi}(I, \phi)>0$. That is, the higher is a firm's $\phi$, the greater is the total and marginal productivity of its project say, due to a greater degree of monopoly power the firm has in its product market. Finally, when $t=\eta$, the firms differ in the levels of their internal funds, $w(\eta)$, with a higher $\eta$ indicating a smaller amount of cash reserves, i.e., $w^{\prime}(\eta)<0$. To streamline the exposition and to better isolate the effects of each parameter, I will assume that the firms always differ along a single dimension, while the other two dimensions are uniform. Also, because a firm's profit when it invests optimally at a given rate of return depends monotonically on $t$, I will sometimes refer to $t$ as the firm's profitability parameter.

In either of these three settings, the equilibrium levels of investment are again determined by an equation analogous to (3), except now this equation is derived from the zero profit condition for the marginal firm. The marginal firm is the firm whose profitability parameter is $\hat{t}$ such that the capital markets clear, that is,

$$
\int_{\hat{t}}^{1} I^{*}(t) d G(t)-S\left(r^{*}\right)=0
$$

where

$$
I^{*}(t)=\arg \max _{I}\left\{V(I, \phi) /\left(1+r^{*}\right)-I-c(\theta, I-w(\eta))\right\}
$$

is the optimal level of investment by a firm with profitability parameter $t$. Let $e(t)=\max \{0, I-$ $w(\eta)\}$ denote firm $t$ 's level of outside financing. The efficiency of investment in the above three frameworks is characterized by the following proposition.

Proposition 4. Suppose that firms differ in their profitability, as measured by parameter $t$. 
(i) The marginal firm, $\hat{t}$, overinvests compared to the frictionless level $\left(I^{*}(\hat{t})>I^{f}(\hat{t})\right)$ if

$$
c_{e}\left(\hat{\theta}, e^{f}(\hat{t})\right)<\frac{c\left(\hat{\theta}, e^{f}(\hat{t})\right)}{I^{f}(\hat{t})},
$$

and underinvests $\left(I^{*}(\hat{t})<I^{f}(t)\right)$ if the reverse is true.

(ii) There exists a $t^{*} \in[0,1]$ such that $I^{*}(t)>I^{f}(t)$ if $t<t^{*}$ and $I^{*}(t)<I^{f}(t)$ if $t>t^{*}$.

As before, the deadweight cost of external capital tends to increase the firms' marginal costs of investment. At the same time, it decreases the equilibrium interest rates, which tends to decrease the marginal cost of investment. Part (i) in Proposition 4 says that these two effects lead to the same qualitative results when firms are heterogeneous as they did when firms were identical. Part (ii) then demonstrates that the effects of costly external finance on a given firm depend on the firm's characteristics in a systematic way. Overinvestment compared to the frictionless level is more likely to be observed in low productivity firms, in firms with large cash reserves, and in firms with low costs of external finance. ${ }^{12}$ This is detailed in the following corollaries.

Corollary 2. Suppose firms differ in the productivity of their projects $(t=\phi)$. Then either all firms overinvest, all firms underinvest, or there is a productivity level $\phi^{*}$ such that all the less productive firms overinvest and all the more productive firms underinvest.

This result follows because more productive firms optimally invest more than less productive firms and therefore, all else equal, need more outside financing. Since the cost function $c(., e)$ is convex, these firms face a higher marginal cost of investment (at optimum) than low productivity

\footnotetext{
${ }^{12}$ Depending on the exact functional forms for $c$ and $G$, it could be that $\hat{t}>t^{*}$, so that $I^{*}(t)<I^{f}(t)$ always. In this case, all but the most profitable firms underinvest, and overinvestment is not a concern.

In general, it is hard to pin down the conditions for $\hat{t}<t^{*}$. Note, however, that Corollary 1 implies (by continuity) that $\hat{t}<t^{*}$ at least for some distribution functions $G$ and cost functions $c$.
} 
firms. Accordingly, more productive firms are more prone to underinvestment, while less productive firms are more prone to overinvestment (due to low interest rates).

Corollary 3. Suppose firms differ in their costs of external finance $(t=\theta)$. Then

(a) either all firms overinvest, all firms underinvest, or there is a costs of external finance $c\left(\theta^{*},.\right)$ such that all firms with less costly external funds overinvest and all firms with more costly external funds underinvest;

(b) the firms with costless external funds $(c(\theta, e)=0$ for all $e)$ always overinvest compared to the first best level.

Corollary 3 confirms the standard partial equilibrium result that, all else equal, a firm's optimal level of investment decreases in its cost of external funds, but in addition it shows that, due to the market equilibrium effects on the rate of return, the firms with the lowest costs of external finance may in fact invest more than in a frictionless world.

Corollary 4. Suppose firms differ in their cash reserves $(t=\eta)$. Then

(a) either all firms overinvest, all firms underinvest, or there is a level of cash reserves $w\left(\eta^{*}\right)$ such that all firms with cash reserves greater than $w\left(\eta^{*}\right)$ overinvest and all firms with cash reserves less than $w\left(\eta^{*}\right)$ underinvest;

(b) the firms with free cash $\left(w(\eta) \geq I^{f}\right)$ always overinvest compared to the first best level.

All else equal, cash poor firms need more outside funds than cash rich firms, which means that, due to the convexity of $c(., e)$, cash poor firms face a higher marginal cost of investment than cash rich firms. Cash poor firms are therefore more likely to underinvest, while cash rich firms are more likely to overinvest. Thus, as in Jensen (1986), free cash induces overinvestment 
in the present model, albeit for a different reason. In Jensen's model, the inefficiencies are due to agency problems in declining industries, whereas here the inefficient overinvestment is due to low equilibrium interest rates: Capital market frictions depress the equilibrium interest rate below what it would be if outside financing were costless, because otherwise the cash poor firms would not be able to survive. Since the cash rich firms do not need to worry about the costs of external finance, this low interest rate leads them to overinvest. Corollary 4 also demonstrates that the paper's main insights continue to hold even if only a small fraction of firms need outside capital.

\subsection{Open economies}

So far, the analysis was conducted under the assumption that the economy is closed to capital flows. It is relatively straightforward to extend the results to a setting where capital can flow freely between countries. Suppose there are two economies, 1 and 2. Economy 1 has perfect capital markets, so that external capital is costless, while in economy 2 external capital is associated with a deadweight cost, $c(., e)$. The supply of external capital provided by the investors in economy $j$ is $S_{j}(r)$, where for simplicity $S_{1}(r)=S_{2}(r)=S(r)$. As in the previous subsection, firms differ in a parameter $t$, which here measures either their productivities $(t=\phi)$ or their cash reserves $(t=\eta) .{ }^{13}$

To avoid the issue of intra-firm transfers of funds across economies, I will assume that each firm can be established only in one or the other economy, but not in both. Moreover, to be able to raise funds in a given economy, a firm has to be established in that economy. It follows that it is not possible for firms established in economy $i$ to directly raise capital in economy $j, i \neq j$. However, if the economies are open, the capital can move freely between the two economies, so a firm established in economy $i$ can be indirectly financed by capital from economy $j$, if this capital flows to economy $i$. This setup ensures that it is not possible for the firms in economy 2 to avoid

\footnotetext{
${ }^{13}$ If the firms only differed in their external costs and the economies opened up to capital flows, all the funds from economy 2 would flow to economy 1 and no firm would get financed in economy 2 .
} 
the deadweight cost associated with raising funds in this economy.

Suppose first the economies are closed to capital flows. As before, the equilibrium rate of return in each economy must be such that the marginal firm earns zero economic profit, while the capital markets clear. That is, in economy $j, j=1,2$, the marginal firm is the firm whose productivity parameter is $\hat{t}_{j}$, given by the market clearing condition

$$
\int_{\hat{t}_{j}}^{1} I_{j}^{*}\left(t, r_{j}^{*}\right) d G(t)-S\left(r_{j}^{*}\right)=0 .
$$

Here

$$
I_{j}^{*}\left(t, r_{j}^{*}\right)=\arg \max _{I}\left\{V(I, \phi) /\left(1+r_{j}^{*}\right)-I-\lambda c(\theta, I-w(\eta))\right\}
$$

is the optimal level of investment by a firm whose profitability parameter is $t$ and was established in economy $j$, with $\lambda=0$ if $j=1$ and $\lambda=1$ if $j=2$. This investment level is given by the first order condition

$$
V_{I}\left(I_{j}^{*}, \phi\right)-\left(1+r_{j}^{*}\right)\left[1+\lambda c_{I}\left(\theta, I_{j}^{*}-w(\eta)\right)\right]=0
$$

To simplify notation, denote the optimal investment level of the marginal firm as $\hat{I}_{j}^{*}$, i.e., $\hat{I}_{j}^{*} \equiv$ $I_{j}^{*}\left(\hat{t}_{j}, r_{j}^{*}\right)$. The zero profit condition for the marginal firm is then

$$
V\left(\hat{I}_{j}^{*}, \phi_{j}^{*}\right) /\left(1+r_{j}^{*}\right)-\hat{I}_{j}^{*}-\lambda c\left(\theta, \hat{I}_{j}^{*}-w\left(\eta_{j}^{*}\right)\right)=0
$$

Conditions (8) - (10) jointly determine the equilibrium in economy $j$.

The first question of interest is which economy offers the higher rate of return. To answer this question, note that holding the rate of return $r_{j}^{*}$ constant, (9) implies that $I_{j}^{*}(t)$ decreases in $\lambda$ for any given $t$, while (10) and the Envelope Theorem imply that $\hat{t}_{j}$ increases in $\lambda$. Hence, $I_{2}^{*}(t)<I_{1}^{*}(t)$ for all $t$ and $\hat{t}_{2}>\hat{t}_{1}$, which means that the left hand side of (8) is smaller in economy 2 than in 
economy 1 if the rate of return is held constant. In a similar way, it is possible to check that $I_{j}^{*}(t)$ decreases and $\hat{t}_{j}$ increases in $r_{j}^{*}$, so that the left hand side of (8) decreases in $r_{j}^{*}$. The comparative statics results of Milgrom and Roberts (1994) then immediately imply that $r_{2}^{*}<r_{1}^{*}$. Moreover, since capital markets are frictionless in economy 1 , the firms in this economy invest at the first best level, so that $r_{2}^{*}<r_{1}^{*}=r^{f}$.

If the economies open themselves to capital flows, capital will flow from economy 2 , in which external financing is costly, to economy 1, where capital markets are frictionless and therefore (initially) offer higher rates of return. This capital reallocation increases the supply of investment funds in economy 1 and decreases in economy 2, causing a decline in the rate of return in economy 1 and an increase in the rate of return in economy 2 , until $r_{1}^{* *}=r_{2}^{* *}=r^{* *}<r^{f}$, where $r_{j}^{* *}$ denotes the equilibrium rate of return in economy $j$ when the two economies are open. This analysis yields the following results.

Proposition 5. Suppose that firms differ in their profitability, as measured by parameter $t$, and that there are two economies open to capital flows: economy 1 with no cost of external capital and economy 2 where external financing is costly. Then:

(a) All firms established in economy 1 overinvest compared to the first best level.

(b) The marginal firm, $\hat{t}_{2}$, established in economy 2 overinvests compared to the first best level if

$$
\frac{1+r^{f}}{1+r^{* *}}>1+c_{e}\left(\theta, e^{f}\left(\hat{t}_{2}\right)\right)
$$

and underinvests if the reverse is true.

(c) Part (ii) of Proposition 4 continues to hold in this setting.

Proposition 5 shows that allowing for perfect capital mobility between economies does not affect 
this paper's main results in any important way. The firms in economy 2 , of course, invest less than the firms in economy 1 , because the equilibrium interest rates are the same in the two economies and the firms in economy 2 also face the additional marginal cost of external finance, $c_{e}(\theta, e)$. However, due to the inflow of capital from economy 2, the firms established in economy 1 overinvest compared to the first best level because the capital inflow decreases the interest rates in economy 1 below the efficient level (i.e., $r^{* *}<r_{1}^{*}=r^{f}$ ). This conclusion holds as long as economy 2 is not so small compared to economy 1 that it does not have any effect on the world interest rates.

On the other hand, the outflow of capital from economy 2 causes the interest rates to rise in this economy, which curbs the investment levels of the firms established in economy 2. Nevertheless, these firms can still overinvest if (a) the rise in the interest rate in economy 2 is not too large (which depends upon the distribution, $G(t)$, of the firms' profitability parameters), and (b) condition (5') is satisfied for the marginal firm in a closed economy 2. These two requirements combine to yield condition (11) in the proposition.

\section{Empirical implications and policy considerations}

While the primary goal of this paper is to clarify the theoretical relation between external cost of financing and investment efficiency, this section briefly discusses some available empirical evidence and some implications of the above analysis for evaluating government policies that affect the costs of raising outside capital.

\subsection{Empirical implications}

One could perhaps imagine dynamic settings in which investment and firm size are only loosely related, but in the static framework explored here, firms that invest more are inevitably larger. Taking this relationship at face value, the model's predictions appear to be consistent with the 
available empirical evidence. In particular, Proposition 4 implies that cash rich firms and the firms with less costly external funds should be bigger. This is consistent with the evidence that larger firms tend to have easier access to outside capital and more internal funds than smaller firms. For example, Mayer (1988) shows that large firms tend to finance their projects from internal funds or through captive or closely related banks. La Porta et al. (1997) show that in the countries with poor creditor protection, a disproportionate share of credit goes to the few largest firms. And according to Altinkilic and Hansen (2000), large firms face lower underwriting spreads than small firms for both equity and bond issues. Thus, there appears to be a positive correlation between a firm's cash reserves and its size, as well as between a firm's cost of external capital and its size. ${ }^{14}$

The model also suggests caution in interpreting evidence about the relationship between the distribution of firm sizes in a given country and the country's costs of external funds. For example, Kumar, Rajan, and Zingales (2002) document that countries with better legal protection of outside investors tend to have bigger firms. The above analysis says that one cannot take this as evidence that the countries with less costly external funds have more efficient firms, because bigger does not imply more efficient in a market equilibrium framework. It could well be that the firms in the low cost countries invest too much compared to the first best level. Proposition 2 says that this would be in particular true if the fixed costs of raising outside capital in these countries were relatively high compared to the marginal costs, and Proposition 5 shows that when capital can flow freely between countries, all firms in a country with frictionless capital markets are too big compared to the first best benchmark (unless, of course, all countries have frictionless capital markets).

\footnotetext{
${ }^{14}$ It is possible, of course, that the causality runs in the opposite direction, i.e., that big firms have easier access to funds because they are big, rather than productivity advantages and cheap funds leading some firms to grow large. One way to capture the former relationship in the present model would be to make the external cost function concave rather than convex. As long as the firms' objective functions remain concave, the main qualitative effect of such a concave external cost should be to increase the equilibrium dispersion of the firms' sizes.
} 


\subsection{The effects of external costs on profits}

One might be tempted to conjecture that a deadweight cost of external finance cannot make firms better off. This conjecture is false, as can be easily shown when firms differ in their level of internal cash reserves or in their productivities. To focus on the argument, suppose that there are only two types of firms: measure $h$ of firms have internal funds equal to $w_{H}$ (type $H$ firms), while the rest of the firms are of type $L$, with internal funds equal to $w_{L}<w_{H}$. There is free entry of the $L$-type firms, which means that the $L$-type firms earn zero profit, while the $H$-type firms earn positive profits, because it is easier for them to avoid the high cost of external capital.

Now consider an increase in the cost of external finance, which drives the equilibrium rates of return down, as in the previous analysis. These changes do not affect the equilibrium profits of the $L$-type firms (who again just break even), but they can benefit the $H$-type firms. In fact, if these firms have enough internal funds to finance all their investments, their profits always increase with the external costs, as can be seen by inspecting their profit function $\pi_{H}=V\left(I_{H}^{*}\right)-\left(1+r^{*}\right) I_{H}^{*} \cdot{ }^{15}$ An important implication of this observation is that the $H$-type firms would have an incentive to oppose any corporate governance reform that would decrease the cost of external financing. This comports well with the observations of La Porta et al (2000) and other authors, who argue that in many countries large corporations (presumably the most productive and/or cash rich firms) tend to oppose reforms of the financial and legal systems that would facilitate external financing. This result also complements the finding of Shleifer and Wolfenzon (2002), who show that in their model a stronger protection of outside investors would be opposed by the marginal (zero-profit) firms.

\footnotetext{
${ }^{15}$ The Envelope Theorem says that the effects of a change in $\theta$ on $I_{H}^{*}$ can be ignored here.
} 


\subsection{Government help to small firms and efficiency}

Many governments sponsor programs that help small businesses to obtain investment funds. For example, Lerner (1999) reports that the U.S. Small Business Innovation Research program allocated over $\$ 7$ billion to small firms between 1983 and 1997. The above analysis does not necessarily mean that such policies are inefficient, but it suggests that it is not hard to find situations where this is the case. To see that a program that helps small businesses with financing could be counterproductive, assume again $L$-type firms and a measure $h$ of $H$-type firms, as in the previous subsection, and suppose that the program allows the $L$ firms to increase the level of their costless funds, $w_{L} .{ }^{16}$

A comprehensive evaluation of a policy should include its effects on consumer surplus, which is outside the scope of this model. However, the following result is suggestive in that it shows that a program of help to small firms could negatively affect the combined surplus of the economy's investors and entrepreneurs.

Proposition 6. Suppose $S\left(r^{*}\right)$ is inelastic and the $H$-type firms find it profitable to seek outside capital. Suppose also that

$$
-\frac{\partial e_{H}^{*}}{\partial w_{L}}<\frac{1}{1+c_{e}^{H}}
$$

Then there exist cutoff values $h_{1} \geq 0$ and $h_{2}>h_{1}$ such that if $h \in\left[h_{1}, h_{2}\right]$ the overall surplus of investors and entrepreneurs decreases in $w_{L}$.

Condition (12) is satisfied in many reasonable settings. For example, it holds when $V(I)=$ $\sqrt{k I-F}($ for $I \geq F)$ and $c(\theta)=\alpha+\theta e$, where $k$ and $\alpha$ are constants.

The intuition behind Proposition 6 is that, all else equal, an increase in the level of $w_{L}$ makes the $L$ firms more profitable, which forces them to bid up the equilibrium interest rate so that their zero

\footnotetext{
${ }^{16}$ If the government needs to raise taxes to finance this program, the conclusion of Proposition 6 would be further reinforced, even if the taxes were non-distortionary, because the tax would decrease the total supply of investment funds, thus decreasing the equilibrium number of firms in the economy.
} 
profit condition is restored. The higher rate of interest increases the marginal cost of investment, leading to a lower equilibrium level of investment for both types of firms, and possibly making the $H$-type firms less profitable. If the number of the $H$-type firms in the economy is relatively high, a decline in their profits causes a decrease in overall welfare.

\section{Conclusion}

Firms often need to rely on outside investors to finance their projects. Given that capital markets are imperfect and involve frictions, external resources come typically at a cost. An important question is then how this cost affects the allocation of resources in the economy. Focusing on an individual firm in isolation, the standard result in the corporate finance literature says that a deadweight cost of external capital will lead firms to underinvest compared to the first-best level and the underinvestment will worsen when the external cost increases. This also seems to imply that when external financing entails a deadweight cost firms must be worse off.

This paper shows that these conclusions do not hold in a market equilibrium setting and cautions against extrapolating the partial equilibrium results when assessing the effects of government policies and corporate governance reforms on economic efficiency. It also highlights that to fully understand how financial frictions distort the allocation of resources in an economy, one needs to examine the effects of external costs on both the aggregate level of investment as well as on the investments of individual firms, as these two effects are in general orthogonal to each other.

While the paper demonstrates that financial markets imperfections affect the allocation of resources across firms in a more complex way than suggested by the existing literature and clarifies some relationships that were previously not recognized, it does not yield a clear-cut policy recommendation on how to best proceed with reforms of the financial and legal systems. Such a recommendation, however, might be feasible after further research, both theoretical and empirical, 
into the exact nature and composition of the deadweight costs associated with external finance.

\section{A. Appendix}

Proof of Proposition 1. Note first that the solution to (3) exists and is unique. The uniqueness was proved in the text. To show existence, evaluate first the left hand side (LHS) and the right hand side (RHS) of (3) at $I^{*}=F$. Using $V(F)=0$, we get

$$
\operatorname{LHS}(3)=V^{\prime}(F) F>-V^{\prime}(F) c(\theta, F-w)=\operatorname{RHS}(3) .
$$

Next, let $e^{*}, I^{*} \rightarrow \infty$. Then $R H S(3)=\lim _{I^{*} \rightarrow \infty} V\left(I^{*}\right) c_{e}\left(\theta, e^{*}\right)=\infty$, while the concavity of $V($. yields $L H S(3)=\lim _{I^{*} \rightarrow \infty}\left[V^{\prime}\left(I^{*}\right) I^{*}-V\left(I^{*}\right)\right]<0$. Hence, $L H S(3)<R H S(3)$ in this case. The existence of a solution to (3) then follows because LHS(3) decreases and RHS(3) increases in $e^{*}$ and $I^{*}$.

Now, in equilibrium, supply of funds must be equal to demand for funds: $I_{A}^{*}=S\left(r^{*}\right)$ and $I_{A}^{f}=S\left(r^{f}\right)$. Thus, $I_{A}^{*}=I_{A}^{f}$ for any $\theta$ if $S(r)$ is completely inelastic. If $S(r)$ is strictly increasing, then $I_{A}^{*}<I_{A}^{f}$ if $r^{*}<r^{f}$, and $\partial I_{A}^{*} / \partial \theta<0$ if $\partial r^{*} / \partial \theta<0$.

I will first show that $r^{*}$ must be decreasing in $\theta$. Consider an initial equilibrium with $\theta=\theta_{1}$ and suppose $\theta$ increases to $\theta_{2}>\theta_{1}$. Because $c$ increases in $\theta$, each firm's cost of financing is higher at $\theta_{2}$ than it was at $\theta_{1}$, and this is true for any investment level. This means that if the interest rate stays the same, each firm makes a negative profit when $\theta=\theta_{2}$, because in the initial equilibrium with $\theta=\theta_{1}$ all firms were making zero expected profits, due to free entry. Since in the new equilibrium the firms that remain in the industry must break even, the interest rate must fall, i.e., it must be $r_{1}^{*}<r_{2}^{*}$

To see that $r^{*}<r^{f}$, it is enough to apply the above argument to the case where the initial 
equilibrium is the first best equilibrium (i.e., there are no external costs). Q.E.D.

Proof of Proposition 2. Evaluate both sides of (3) at $I=I^{f}$. The concavity of the firm's objective function implies that $I^{f}<I^{*}$ if and only if the left hand side of (3) is greater than the right hand side. From (4), the left hand side of (3) evaluated at $I^{f}$ is zero. Hence, $I^{f}<I^{*}$ if and only if the right hand side of (3) evaluated at $I^{f}$ is greater than zero. Substituting for $V\left(I^{f}\right)$ from condition (4) yields condition (5) in the proposition. Q.E.D.

Proof of Corollary 1. If $c(\theta, e)=\alpha(\theta)+\beta(\theta) e$, then $c_{e}(\theta, e) e=\beta(\theta) e<\alpha(\theta)+\beta(\theta) e=c(\theta, e)$ for all $\theta$ and $e$, because $\alpha(\theta)>0$. Hence, it must be $c_{e}\left(\theta, e^{f}\right)<c\left(\theta, e^{f}\right) / e^{f}$, which means that (5) always holds when $w=0$. Q.E.D.

Proof of Proposition 3. Differentiating (5) implicitly with respect to $\theta$ yields

$$
\frac{\partial I^{*}(\theta)}{\partial \theta}=\frac{V^{\prime}\left(I^{*}\right) c_{\theta}\left(\theta, e^{*}\right)-V\left(I^{*}\right) c_{\theta e}\left(\theta, e^{*}\right)}{V\left(I^{*}\right) c_{e e}\left(\theta, e^{*}\right)-V^{\prime \prime}\left(I^{*}\right)\left[I^{*}+c\left(\theta, e^{*}\right)\right]}
$$

Due to concavity of $V(I)$, the denominator is always positive. The sign of $\partial I^{*}(\theta) / \partial \theta$ is thus determined by the sign of the numerator. Solving for $V\left(I^{*}\right)$ from condition (3) and substituting to the numerator yields $\partial I^{*}(\theta) / \partial \theta<0$ if and only if $c_{\theta}\left(\theta, e^{*}\right)\left[1+c_{e}\left(\theta, e^{*}\right)\right]<c_{\theta e}\left(\theta, e^{*}\right)\left[I^{*}+c\left(\theta, e^{*}\right)\right]$. Using $c(\theta, e)=\theta(A+e)$, this condition simplifies to $A<w$. Q.E.D.

Proof of Proposition 4. (i) Since the equilibrium interest rate is determined by the zero profit condition for the marginal firm, this part is proved exactly the same way as Proposition 2.

(ii) The profit-maximizing investment level of a firm $t, I^{*}(t)$, is given by the first order condition

$$
V_{I}\left(I^{*}, \phi\right)-\left(1+r^{*}\right)\left[1+c_{I}\left(\theta, I^{*}-w(\eta)\right)\right]=0
$$


When $t=\phi$, implicit differentiation of (13) with respect to $\phi$ yields

$$
\frac{\partial I^{*}(\phi)}{\partial \phi}=\frac{V_{I \phi}\left(I^{*}, \phi\right)}{\left(1+r^{*}\right) c_{e e}\left(., e^{*}\right)-V_{I I}\left(I^{*}, \phi\right)} .
$$

Similarly, from the first order condition for the first-best level of investment, $I^{f}(\phi)$, one gets

$$
\frac{\partial I^{f}(\phi)}{\partial \phi}=-\frac{V_{I \phi}\left(I^{f}, \phi\right)}{V_{I I}\left(I^{f}, \phi\right)} .
$$

Now suppose there exists a $\bar{\phi}$ such that $I^{*}(\bar{\phi})=I^{f}(\bar{\phi})$. Then $\partial I^{f}(\bar{\phi}) / \partial \phi>\partial I^{*}(\bar{\phi}) / \partial \phi$, so that $I^{*}(\phi)-I^{f}(\phi)$ decreases in $\phi$ at $\phi=\bar{\phi}$. Hence, $I^{*}(\phi)$ and $I^{f}(\phi)$ can cross at most once. This implies that $I^{*}(\phi)-I^{f}(\phi)<0$ for $\phi>\bar{\phi}$ and $I^{*}(\phi)-I^{f}(\phi)>0$ for $\phi<\bar{\phi}$. In this case, $\phi^{*}=\bar{\phi}$. If there is no $\bar{\phi}$ such that $I^{*}(\bar{\phi})=I^{f}(\bar{\phi})$, then it must be either $I^{*}(\phi)>I^{f}(\phi)$ for all $\phi$, in which case $\phi^{*}=1$, or $I^{*}(\phi)<I^{f}(\phi)$ for all $\phi$, in which case $\phi^{*}=0$.

When $t=\eta$, then $\partial I^{*}(\eta) / \partial \eta=\left(1+r^{*}\right) c_{e e}\left(., e^{*}\right) w^{\prime}(\eta) /\left[\left(1+r^{*}\right) c_{e e}\left(., e^{*}\right)-V_{I I}\left(I^{*}\right)\right]<0$, while $I^{f}(\eta)$ is independent of $\eta$, i.e., $\partial I^{f}(\eta) / \partial \eta=0$. Similarly, when $t=\theta$, then $\partial I^{*}(\theta) / \partial \theta=-(1+$ $\left.r^{*}\right) c_{e \theta}\left(\theta, e^{*}\right) /\left[\left(1+r^{*}\right) c_{e e}\left(\theta, e^{*}\right)-V_{I I}\left(I^{*}, \phi\right)\right]<0$ and $\partial I^{f}(\theta) / \partial \theta=0$. Therefore, $\partial I^{f}(t) / \partial t-$ $\partial I^{*}(t) / \partial t<0$ in these two cases, so that $I^{*}(t)-I^{f}(t)$ decreases in $t$, which immediately implies the claim. Q.E.D.

Proof of Corollary 2. Follows directly from Proposition 4. Q.E.D.

Proof of Corollary 3. Part (a) follows directly from Proposition 4. Part (b): A firm $\theta$ overinvests if and only if its marginal cost of investment, $\left(1+r^{*}\right)\left[1+c_{I}\left(\theta, I^{f}(\eta)-w(\eta)\right)\right]$, is lower than the efficient marginal cost, $1+r^{f}$, that is, if and only if

$$
\frac{1+r^{f}}{1+r^{*}}>1+c_{I}\left(\theta, I^{f}(\eta)-w(\eta)\right)
$$


For the firms with $c_{e}(\theta, e)=0$ this reduces to $\frac{1+r^{f}}{1+r^{*}}>1$, which always holds because $r^{*}<r^{f}$. Q.E.D.

Proof of Corollary 4. Part (a) follows directly from Proposition 4. In part (b), the logic is the same as in part (b) of Corollary 3. When $w(\eta)>I^{f}(\eta)$, then $c_{I}\left(., I^{f}(t)-w(\eta)\right)=0$ for this firm and (14) reduces to $\frac{1+r^{f}}{1+r^{*}}>1$, which always holds because $r^{*}<r^{f}$. Q.E.D.

Proof of Proposition 5. (a) This claim follows directly from the first order condition (9) (where $\lambda=0)$ and from $r^{* *}<r_{1}^{*}=r^{f}$.

(b) A firm with productivity $t$ established in economy 2 overinvests if and only if its marginal cost of investment at the efficient level, $\left(1+r^{* *}\right)\left[1+c_{I}\left(\theta, I^{f}(t)-w(\eta)\right)\right]$, is lower than the efficient marginal cost, $1+r^{f}$, that is, if and only if (11) holds.

(c) This part holds because the first order conditions for the firms investments, both in the presence and in the absence of a deadweight cost $C(\theta, e)$, are the same whether the economy is open or closed, and because $r^{* *}<r^{f}$. Hence, the proofs of parts (ii) and (iii) of Proposition 4 apply also when the economies are open. Q.E.D.

Proof of Proposition 6. When the $H$ firms find it profitable to seek outside capital, their profits are given by $\pi_{H}=V\left(I_{H}^{*}\right)-\left(1+r^{*}\right)\left[c\left(\theta, e_{H}^{*}\right)+I_{H}^{*}\right]$. Suppose $S^{\prime}\left(r^{*}\right)=0$, so that the total amount of investment funds available in this economy (including the firms' cash reserves, $w$ ) is fixed. Denote this amount as $E$. The total welfare in this economy, $W(\theta)$, is then given by the sum of the returns on the available investment funds plus the profits of the $H$ firms: $W(\theta)=E\left(1+r^{*}\right)+$ $h \pi_{H}$. Differentiating this with respect to $w_{L}$ and using the Envelope Theorem yields $\frac{\partial W\left(w_{L}\right)}{\partial w_{L}}=$ $\frac{\partial\left(1+r^{*}\right)}{\partial w_{L}}\left(S\left(r^{*}\right)-h c^{H}-h I_{H}^{*}\right)-\frac{\partial e_{H}^{*}}{\partial w_{L}} h\left(1+r^{*}\right)\left(c_{e}^{H}+1\right)-\left(1+r^{*}\right)$. If $h$ is sufficiently close to $h^{* *}=\frac{S\left(r^{*}\right)}{I_{H}^{*}}$, then $S\left(r^{*}\right)-h c^{H}-h I_{H}^{*}<0$. Since $\frac{\partial\left(1+r^{*}\right)}{\partial w_{L}}>0$ (as will be shown shortly), the first term in the expression for $\frac{\partial W\left(w_{L}\right)}{\partial w_{L}}$ is negative. Hence, a sufficient condition for $\frac{\partial W\left(w_{L}\right)}{\partial w_{L}}<0$ is that the sum 
of the last two terms is negative as well, which holds if (12) holds. Therefore, $\frac{\partial W\left(w_{L}\right)}{\partial w_{L}}<0$ if $(12)$ holds and $h$ is sufficiently close to $h_{2}=h^{* *}$. To finish the proof, notice that from the zero profit condition for the $L$-type firms, $\frac{\partial\left(1+r^{*}\right)}{\partial w_{L}}=\frac{V^{\prime}\left(w_{L}+e_{L}^{*}\right)-\left(1+r^{*}\right)}{c^{L}+I_{L}^{*}}>0$, where the inequality follows because $V^{\prime}\left(w_{L}+e_{L}^{*}\right)=\left(1+r^{*}\right)\left(c_{e}^{L}+1\right)$ from the first order condition for $e_{L}^{*}$. Q.E.D. 


\section{References}

[1] Aghion, P., and P. Bolton. "A trickle-down theory of growth and development with debt overhang." Review of Economic Studies 64(2), 1997, 151-72.

[2] Altinkilic, O., and R. S. Hansen. "Are There Economies of Scale in Underwriting Fees? Evidence of Rising External Financing Costs." Review of Financial Studies 13(1), 2000, 191-218.

[3] Almeida, H., and D. Wolfenzon. "The Effect of External Finance on the Equilibrium Allocation of Capital." Journal of Financial Economics 75(1), 2005, 133-164.

[4] Banerjee, A.V., and E. Duflo. "Growth Theory Through the Lens of Development Economics," in Handbook of Economic Growth Vol. 1A, edited by P. Aghion and S. Durlauf. North Holland, $2005,473-552$.

[5] Bencivenga, V. R., B. D. Smith and R. M. Starr. "Transactions Costs, Technological Choice, and Endogenous Growth." Journal of Economic Theory 67(1), 1995, 153-77.

[6] Bernhardt, D., and H. Lloyd-Ellis. "Enterprise, Inequality and Economic Development." Review of Economic Studies 67(1), 2000, 147-68.

[7] Boyd, J. H., and B. D. Smith. "Intermediation and the Equilibrium Allocation of Investment Capital: Implications for Economic Development." Journal of Monetary Economics 30(3), 1992, 409-32.

[8] Froot, K. A., Scharfstein, D. S., and J. C. Stein. "Risk Management: Coordinating Corporate Investment and Financing Policies." Journal of Finance 48(5), 1993, 1629-58.

[9] Gale, D., and M. Hellwig. "Incentive-Compatible Debt Contracts: The One-Period Problem." Review of Economic Studies 52(4), 1985, 647-63. 
[10] Greenwald, B., Stiglitz, J. E., and A. Weiss. "Informational Imperfections in the Capital Market and Macroeconomic Fluctuations", American Economic Review 74(2), 1984, 194-99.

[11] Harris, M., and A. Raviv. "The Theory of Capital Structure." Journal of Finance 46(1), 1991, 297-355.

[12] Hubbard, R. G. "Capital-Market Imperfections and Investment." Journal of Economic Literature 36(1), 1998, 193-225.

[13] Jensen, M. C. "Agency Costs of Free Cash Flow, Corporate Finance, and Takeovers." American Economic Review 76(2), 1986, 323-29.

[14] Kaplan, S. and L. Zingales. "Do Investment-Cash Flow Sensitivities Provide Useful Measures of Financing Constraints?" Quarterly Journal of Economics 112(1), 1997, 169-215.

[15] Kumar, K., Rajan, R., and L. Zingales. "What Determines Firm Size?” Manuscript, University of Chicago, 2002.

[16] La Porta, R., Lopez-de-Silanes, F., Shleifer, A., and R. W. Vishny. "Investor Protection and Corporate Governance." Journal of Financial Economics 58(1-2), 2000, 3-27.

[17] La Porta, R., Lopez-de-Silanes, F., Shleifer, A., and R. W. Vishny. "Legal determinants of external Finance." Journal of Finance 52(3), 1997, 1131-1150.

[18] Lerner, J. "The Government as Venture Capitalist: The Long-Run Impact of the SBIR Program." Journal of Business 72(3), 1999, 285-318.

[19] Levine, R. "Finance and Growth: Theory and Evidence," in Handbook of Economic Growth, edited by Philippe Aghion and Steven Durlauf. The Netherlands: Elsevier Science, 2005, 865934. 
[20] Matsusaka, J. G., and V. Nanda. "Internal Capital Markets and Corporate Refocusing." Journal of Financial Intermediation 11(2), 2002, 176-211.

[21] Mayer, C., "New issues in corporate Finance." European Economic Review 32(2-3), 1988, $1167-1188$.

[22] Milgrom, P., and J. Roberts. "Comparing equilibria." American Economic Review 84(3), 1994, $441-459$.

[23] Myers, S. C. "Determinants of Corporate Borrowing." Journal of Financial Economics 5(2), 1977, 147-75.

[24] Myers, S. C., and N. S. Majluf. "Corporate Financing and Investment Decisions When Firms Have Information That Investors Do Not Have." Journal of Financial Economics 13(2), 1984, $187-221$.

[25] Restuccia, D., and R. Rogerson. "Policy Distortions and Aggregate Productivity with Heterogeneous Plants." Working Paper 283, University of Toronto, 2007.

[26] Shleifer, A., and D. Wolfenzon. "Investor protection and equity markets." Journal of Financial Economics 66(1), 2002, 3-27.

[27] Stein, J. C. "An Adverse-Selection Model of Bank Asset and Liability Management with Implications for the Transmission of Monetary Policy." RAND Journal of Economics 29(3), 1998, 466-86.

[28] Stein, J. C. "Agency, Information and Corporate Investment", in Handbook of the Economics of Finance, edited by G. Constantinides, M. Harris and R. Stulz, 2003, 111-165.

[29] Townsend, R. M. "Optimal Contracts and Competitive Markets with Costly State Verification." Journal of Economic Theory 21(2), 1979, 265-93. 